\title{
Pressurized planar electrochromatography of DNS amino acids derivatives in silica gel and silanized silica gel systems with formic acid addition to the water mobile phase
}

\author{
Adam Chomicki ${ }^{1} \cdot$ Tadeusz H. Dzido ${ }^{1}$ \\ Received: 12 February 2021 / Accepted: 20 April 2021 / Published online: 13 May 2021 \\ (c) The Author(s) 2021
}

\begin{abstract}
Pressurized planar electrochromatography (PPEC) of dansyl (DNS) derivatives of amino acids in normal- and reversed-phase systems is presented. The results have been obtained for mobile phases with different acetonitrile (ACN) concentrations $(0-85 \%)$. The data obtained show differences in separation selectivity between high-performance thin-layer chromatography (HPTLC) and PPEC systems. These differences originate from the electrophoretic effect which is involved in the PPEC system, contrary to the HPTLC one.
\end{abstract}

Keywords Pressurized planer electrochromatography $\cdot$ PPEC $\cdot$ Amino acids $\cdot$ Dansyl amino acids

\section{Introduction}

Amino acids are a significant group of biochemical compounds. They have many industrial applications, especially in the pharmacy or nutrition industry. Moreover, the determination of the amino acids is used for the diagnosis of various diseases, such as cancer, neurological disorders, metabolic diseases, disorders in the functioning of the liver or kidneys [1-6]. Chromatographic techniques are widely used in the study and analysis of the samples related to these aspects. High-performance liquid chromatography (HPLC) and capillary electrophoresis techniques are characterized by high efficiency and short separation time [7-12]. Thin-layer chromatography (TLC/HPTLC) of amino acids [13-20] and their dansyl (DNS) derivatives [21-27] has been widely described in the scientific literature. Pressurized planar electrochromatography (PPEC) is also included in the current research on amino acid separation. This technique is attractive to that application due to its short separation time and high performance [28-38]. The different separation selectivity in comparison with liquid chromatography

Adam Chomicki

adam.chomicki@umlub.pl

1 Department of Physical Chemistry, Medical University of Lublin, Chodźki 4a Str., 20-098 Lublin, Poland and electrophoresis is also an essential advantage of PPEC $[35,36,39,40]$.

Polak et al. [41-45] reported the use of PPEC to separate amino acids enantiomers and diastereoisomers. In previous papers by our group, we reported two-dimensional separation of some amino acids by HPTLC and PPEC on HPTLC RP-18W plates [39] and the comparison of separation selectivity of 20 biogenic amino acids in TLC and PPEC in systems with silica gel and water mobile phase [40].

Gwarda et al. [46-50] presented extensive research on peptides chromatography in HPTLC and PPEC systems with silica and silica-based C18 stationary phases. They reported interesting data on the solutes retention and selectivity depending on ion-pairing reagent in the mobile phase $[47,49]$. According to these papers, the addition of trifluoroacetic acid (TFA) to the mobile phase led to a considerable reduction of peptide tailing zones. It was revealed that TFA addition was more effective for RP-HPTLC peptide separation than formic acid (FA) [46]. However, the TFA addition resulted in high electric current and high Joule heat generation during the PPEC process [48]. Based on these data, it was interesting to apply analogous systems to separation of DNS amino acids derivatives. However, in order to avoid the mentioned problems with high current and Joule heat generation in PPEC systems, the FA addition to the mobile phase was applied in the research presented.

This paper stands for a continuation of the research mentioned above and shows differences in the separation 
selectivity of DNS amino acids between HPTLC and PPEC systems.

\section{Experimental}

\subsection{Materials used}

All reagents used were of analytical grade. Acetonitrile, acetone, diethyl ether, formic acid 98-100\%, sodium bicarbonate, hydrochloric acid (35-38\%), sodium sulfate were supplied by POCh (Gliwice, Poland), dansyl chloride was from Sigma-Aldrich (St Louis, MO, USA). The deionized water was produced in the department using demineralizer HLP 5 (Hydrolab, Straszyn, Poland). The solutions of the mobile phase were prepared by mixing acetonitrile with formic acid and deionized water. All experiments were performed with HPTLC silica gel $60 \mathrm{~F}_{254 \mathrm{~s}}$ and HPTLC RP-18W plates, both from Merck (Darmstadt, Germany). The amino acids investigated were tyrosine (Tyr), glycine (Gly), alanine (Ala), asparagine (Asn), arginine (Arg), lysine (Lys), glutamic acid (Glu), valine (Val), phenylalanine (Phe), histidine (His), isoleucine (Ile), methionine (Met), leucine (Leu), aspartic acid (Asp), proline (Pro), serine (Ser), threonine (Thr), tryptophan (Trp), glutamine (Gln), cysteine (Cys), citrulline (Cit), all from Sigma-Aldrich.

\subsection{Mobile phase preparation}

The mobile phase solutions were prepared by adding formic acid to deionized water or to acetonitrile and deionized water mixtures (the final concentration of FA in the mobile phase was equal to $265 \mathrm{mmol} / \mathrm{dm}^{3}$ ).

\subsection{DNS derivatives of amino acids}

DNS derivatives of amino acids were obtained according to the LeFevre procedure [51, 52]. A quantity of $2 \mathrm{mg}$ of each amino acid was dissolved in $6.7 \mathrm{~mL}$ of $0.2 \mathrm{M}$ sodium bicarbonate. The obtained solution was mixed with $6.7 \mathrm{~mL}$ of $5.5 \mathrm{mM}$ dansyl chloride; the solution $\mathrm{pH}$ was within the optimal range for the dansylation reaction (8.5-10.5), and shaken for $1 \mathrm{~min}$, then allowed to stay for $90 \mathrm{~min}$ in the dark at room temperature. After this time, hydrochloric acid was added until the $\mathrm{pH}$ was equal to 4.0. Then, the obtained samples were extracted three times by diethyl ether. The obtained solutions were combined and filtered through anhydrous sodium sulfate crystals, and then the solution was allowed to evaporate the solvent. The obtained DNS amino acids were dissolved in $2 \mathrm{~mL}$ of acetone.

\subsection{Pressurized planar electrochromatography}

\subsubsection{Plate preparation}

The margins of $5 \mathrm{~mm}$ width of impregnating agent comprised both Sarsil W and Sarsil H50 (Zakłady Chemiczne "Silikony Polskie," Nowa Sarzyna, Poland) were produced on the whole periphery of adsorbent layer of the plates [37]. Before experiments, the HPTLC silica gel $60 \mathrm{~F}_{254 \mathrm{~s}}$ and HPTLC RP-18W plates were washed by dipping in methanol for $1 \mathrm{~min}$ and dried in the air and in the oven at temperature $105-110{ }^{\circ} \mathrm{C}$ for $15 \mathrm{~min}$. Solutions of the amino acids were applied on the plate using Automatic TLC Sampler (CAMAG, Muttenz, Switzerland). The distance of the marginal starting spots to both left and right chromatographic plate side edges was equal to $15 \mathrm{~mm}$, and the distance of start line from lower chromatographic plate edge was $16 \mathrm{~mm}$.

\subsubsection{Pressurized planar electrochromatography procedure}

All PPEC experiments were performed with a PPEC chamber designed for $10 \mathrm{~cm} \times 20 \mathrm{~cm}$ plates [53] according to the same procedure as presented in the previous work [40]. All PPEC experiments were performed in triplicate.

\subsection{Detection and documentation}

Chromatograms were taken with TLC Visualizer (CAMAG). The retardation factor values were determined with a VideoScan TLC/HPTLC evaluation software (CAMAG).

\section{Results and discussion}

The data of migration distance of the solutes depending on the acetonitrile concentration, in the range $0-40 \%$ (HPTLC silica gel $60 \mathrm{~F}_{254 \mathrm{~s}}$ plates) and 10-85\% (HPTLC RP-18W plates) in aqueous formic acid solution, are presented in Tables 1 and 2, respectively.

For silica gel plates (Table 1), a significant increase in the migration distance of DNS amino acids was observed with increasing concentration of acetonitrile in the mobile phase in the range of $0-25 \%$ (an increase between $9.3 \mathrm{~mm}$ for DNS-Cit and $43.8 \mathrm{~mm}$ for DNS-Cys). This is in line with the previous report [54]. For $25 \% \mathrm{ACN}$ in the mobile phase compared to $20 \%$, a reduction of the difference in the migration distance of DNS amino acids was observed (migration distance differences for $20 \% \mathrm{ACN} \leq 39.4 \mathrm{~mm}$; for $25 \% \leq 27 \mathrm{~mm}$ ). Regarding the higher concentrations of $30 \%$ and $40 \%$ ACN, the migration distance of DNS amino 
Table 1 The DNS amino acid migration distances $(\mathrm{mm})$ in PPEC systems with HPTLC silica gel $60 \mathrm{~F}_{254 \mathrm{~s}}$ plates (Merck) and acetonitrile in the concentration range from 0 to $40 \%$ in water-formic acid solution (the final concentration of formic acid in the mobile phase was equal to $265 \mathrm{mmol} /$ $\mathrm{dm}^{3}$ ), polarization voltage $0.500 \mathrm{kV}$, separation time $15 \mathrm{~min}$

\begin{tabular}{lclllll}
\hline \% Acetonitrile & $0 \%$ & $10 \%$ & $20 \%$ & $25 \%$ & $30 \%$ & $40 \%$ \\
\hline DNS-Tyr & 33.4 & 39.6 & 53.2 & 56.4 & 51.3 & 46.8 \\
DNS-Gly & 35.5 & 44.3 & 53.8 & 58.9 & 50.6 & 47.4 \\
DNS-Ala & 32.8 & 42.3 & 52.6 & 58.9 & 51.3 & 47.6 \\
DNS-Asn & 25.8 & 32.4 & 40.0 & 47.8 & 51.8 & 47.9 \\
DNS-Arg & 37.5 & 49.65 & 64.5 & 62.4 & 52.1 & 48.7 \\
DNS-Lys & 11.7 & 23.6 & 33.2 & 45.6 & 51.5 & 49.0 \\
DNS-Glu & 35.7 & 42.0 & 47.9 & 54.6 & 51.9 & 49.5 \\
DNS-Val & 26.1 & 39.2 & 46.4 & 56.1 & 52.1 & 51.0 \\
DNS-Phe & 22.9 & 35.8 & 44.5 & 53.4 & 52.1 & 51.4 \\
DNS-His & 7.1 & 18.7 & 25.7 & 35.4 & 52.5 & 51.8 \\
DNS-Ile & 23.7 & 37.4 & 47.9 & 54.9 & 51.7 & 52.2 \\
DNS-Met & 24.4 & 38.0 & 47.1 & 55.3 & 52.1 & 52.1 \\
DNS-Leu & 22.5 & 37.1 & 47.2 & 52.8 & 53.2 & 52.4 \\
DNS-Asp & 35.5 & 42.7 & 50.1 & 57.3 & 54.4 & 52.6 \\
DNS-Pro & 19.2 & 36.6 & 46.6 & 55.3 & 54.6 & 51.9 \\
DNS-Ser & 35.0 & 46.2 & 52.4 & 59.3 & 56.0 & 51.1 \\
DNS-Thr & 19.2 & 33.9 & 43.3 & 50.6 & 56.0 & 50.6 \\
DNS-Trp & 23.0 & 30.3 & 46.7 & 55.4 & 56.5 & 49.7 \\
DNS-Gln & 37.8 & 57.9 & 65.4 & 56.1 & 55.6 & 48.7 \\
DNS-Cys & 11.0 & 28.1 & 40.1 & 54.8 & 53.3 & 45.9 \\
DNS-Cit & 44.3 & 58.81 & 62.2 & 53.6 & 53.0 & 44.4 \\
\hline & & & & & &
\end{tabular}

Table 2 The DNS amino acid migration distances $(\mathrm{mm})$ in PPEC systems with HPTLC RP-18W plates (Merck) and acetonitrile in the concentration range from 10 to $85 \%$ in waterformic acid solution (the final concentration of formic acid in the mobile phase was equal to $265 \mathrm{mmol} / \mathrm{dm}^{3}$ ), polarization voltage $0.500 \mathrm{kV}$, separation time $15 \mathrm{~min}$

\begin{tabular}{lrrrrrr}
\hline \% Acetonitrile & $10 \%$ & $25 \%$ & $40 \%$ & $55 \%$ & $70 \%$ & $85 \%$ \\
\hline DNS-Tyr & 7.24 & 15.02 & 27.76 & 31.11 & 18.77 & 35.40 \\
DNS-Gly & 9.12 & 17.97 & 24.94 & 25.48 & 14.35 & 33.52 \\
DNS-Ala & 8.32 & 15.29 & 23.06 & 27.36 & 14.75 & 34.06 \\
DNS-Asn & 6.44 & 9.79 & 17.57 & 28.16 & 14.62 & 34.06 \\
DNS-Arg & 5.63 & 7.64 & 32.05 & 27.36 & 16.36 & 35.94 \\
DNS-Lys & 1.07 & 3.62 & 8.45 & 10.59 & 13.54 & 34.73 \\
DNS-Glu & 8.85 & 18.64 & 25.48 & 24.94 & 14.22 & 33.12 \\
DNS-Val & 5.10 & 7.78 & 15.69 & 20.65 & 14.22 & 34.46 \\
DNS-Phe & 2.55 & 6.17 & 11.40 & 18.51 & 14.22 & 33.52 \\
DNS-His & 0.81 & 3.22 & 8.32 & 27.76 & 13.68 & 32.19 \\
DNS-Ile & 3.09 & 5.63 & 12.74 & 20.25 & 13.68 & 34.33 \\
DNS-Met & 4.56 & 7.24 & 15.15 & 20.12 & 13.68 & 32.99 \\
DNS-Leu & 2.95 & 5.90 & 10.59 & 19.58 & 13.68 & 34.87 \\
DNS-Asp & 9.12 & 17.30 & 25.48 & 27.09 & 14.35 & 29.50 \\
DNS-Pro & 4.02 & 7.78 & 15.83 & 22.80 & 13.54 & 34.33 \\
DNS-Ser & 9.93 & 20.65 & 30.58 & 26.15 & 13.68 & 31.38 \\
DNS-Thr & 2.68 & 5.63 & 9.79 & 25.75 & 14.88 & 31.38 \\
DNS-Trp & 2.41 & 6.97 & 15.69 & 23.20 & 15.02 & 35.67 \\
DNS-Gln & 10.73 & 20.88 & 36.07 & 25.61 & 16.62 & 35.94 \\
DNS-Cys & 1.07 & 7.78 & 10.86 & 16.90 & 10.59 & 29.36 \\
DNS-Cit & 4.29 & 19.84 & 30.84 & 26.55 & 18.64 & 34.19 \\
\hline & & & & & &
\end{tabular}

acids was of low diversity (migration distance differences for $30 \% \leq 5.9 \mathrm{~mm}$; for $40 \% \leq 8.2 \mathrm{~mm}$ ). The exemplary electrochromatogram of DNS amino acids is presented in Fig. 1.
In Fig. 2, the correlation of retardation factor values of the DNS amino acids in HPTLC silica gel system with formic acid-water solution $\left(265 \mathrm{mmol} / \mathrm{dm}^{3}\right)$ [54] against their 
Fig. 1 Electrochromatogram of DNS amino acids, mobile phase: water solution of formic acid, the final concentration of formic acid in the mobile phase was equal to $265 \mathrm{mmol} / \mathrm{dm}^{3}$, HPTLC silica gel $60 \mathrm{~F}_{254}$ s plate from Merck, polarization voltage $0.500 \mathrm{kV}$, separation time $15 \mathrm{~min}$ (EOF - electroosmotic flow)

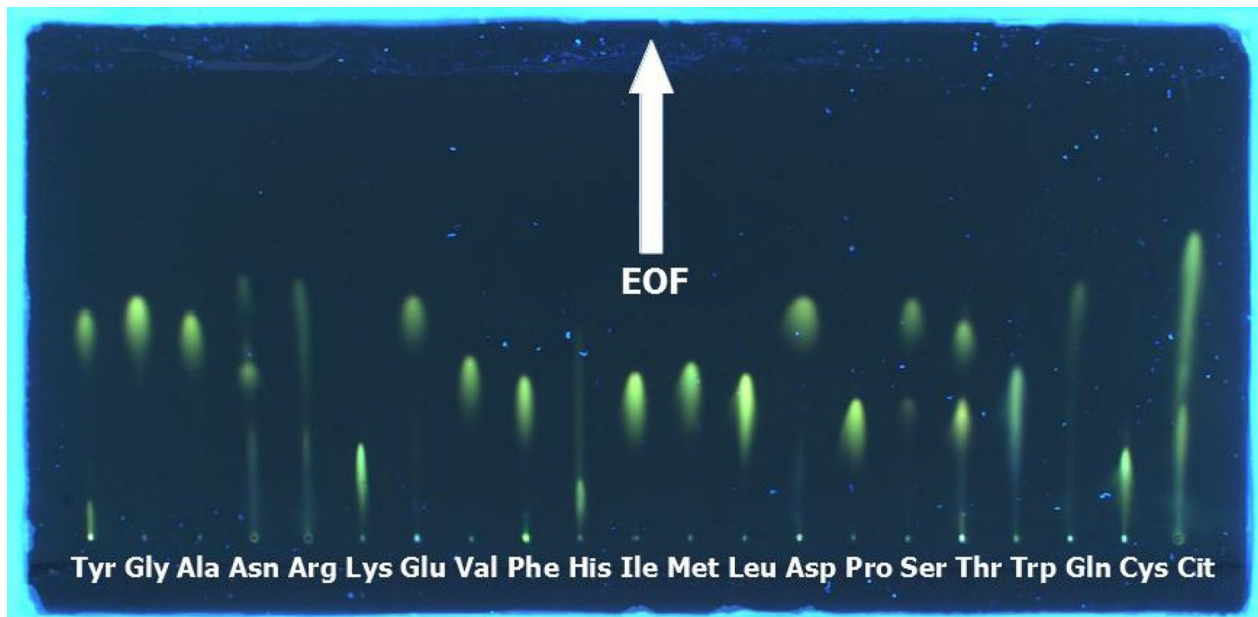

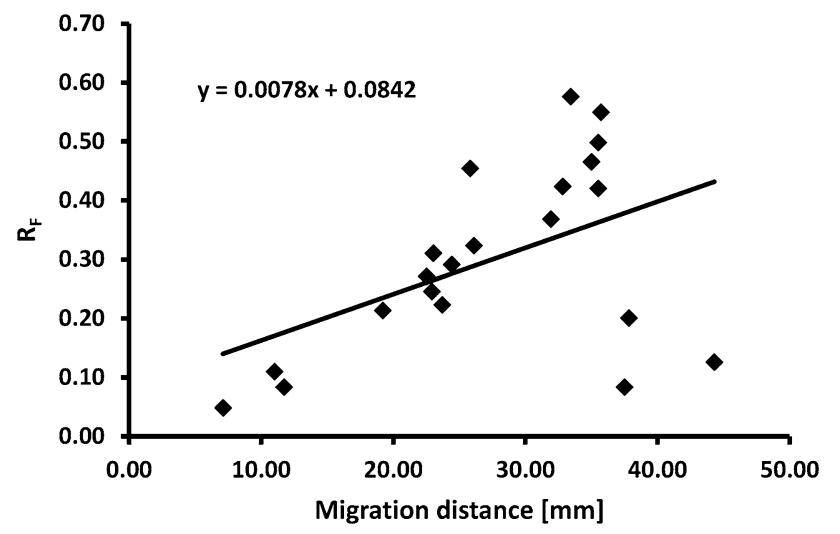

Fig. 2 Comparison of the $R_{\mathrm{F}}$ values of the DNS amino acids in HPTLC system with the migration distances in PPEC one. The silica gel $60 \mathrm{~F}_{254 \mathrm{~s}}$ plates and formic acid-water solution $\left(265 \mathrm{mmol} / \mathrm{dm}^{3}\right)$ were used in both techniques

migration distances values in PPEC system comprising the same adsorbent layer and mobile phase is presented. It is shown that the separation selectivities produced by the two systems are different $(R=0.4796)$. It means that the electrophoresis effect involved in the PPEC process significantly altered the separation of the solutes in comparison with HPTLC. It should be noted that despite the low $\mathrm{pH}$ of the mobile phase (formic acid in the mobile phase), the data obtained suggest that the acid groups of DNS amino acids were at least partially dissociated. So DNS amino acids' electrophoretic mobility affected the change in separation selectivity in PPEC in comparison with that in HPTLC.

For RP-18W plates (Table 2), an increase in the migration distance of DNS amino acids was observed with increasing concentration of acetonitrile in the mobile phase in the range of 10-55\% (an increase between $9.52 \mathrm{~mm}$ for DNSLys and $26.95 \mathrm{~mm}$ for DNS-His). It is characteristic of the reversed-phase system. However, for $70 \% \mathrm{ACN}$ in the mobile phase compared to 55\%, except DNS-Lys, the solute migration distances decreased (a decrease between $5.9 \mathrm{~mm}$ for DNS-Leu and $14.80 \mathrm{~mm}$ for DNS-His), and in addition, they migrated distances of low diversity (migration distance differences for $55 \% \mathrm{ACN} \leq 20.52 \mathrm{~mm}$; for $70 \% \leq 8.18 \mathrm{~mm}$ ). For $85 \% \mathrm{ACN}$ in the mobile phase compared to $70 \% \mathrm{ACN}$, solute migration increased (an increase between $15.15 \mathrm{~mm}$ for DNS-Asp and $20.79 \mathrm{~mm}$ for DNS-Pro), and all DNS amino acids showed minor diversity in the migration distances (migration distance differences $\leq 6.58 \mathrm{~mm}$ ) similarly as for $70 \%$ ACN. The discussed effect can be concerned with change of the stationary phase structure, which is dependent on modifier concentration in the mobile phase. For lower $\mathrm{ACN}$ concentration in the mobile phase, $\mathrm{C} 18$ ligands of the adsorbent surface are expelled from the mobile phase and for higher ACN concentration are embedded in it. Then, in the latter case, the adsorbent capacity of the stationary phase increases in comparison with the former. Similar effects have been previously described in publications [55, 56]. The exemplary electrochromatogram of DNS amino acids is presented in Fig. 3.

Correlation of the data obtained for HPTLC RP-18W system [54] with those for PPEC RP-18W, one revealed substantial changes of separation selectivity of the solutes. It is exemplified in Fig. 4 where the retardation factor values of the solutes investigated in HPTLC system are plotted against migration distances values in the PPEC one (the mobile phase comprised $40 \%$ ACN in FA water solution, $y=0.0084 x+0.1118 ; R=0.656)$. These data evidence that the electrophoretic effect significantly changes the separation selectivity in the PPEC system in comparison with that in the HPTLC one. 
Fig. 3 Electrochromatogram of DNS amino acids, mobile phase: $40 \%$ ACN in water-formic acid solution (the final formic acid concentration in the mobile phase was equal to $265 \mathrm{mmol} / \mathrm{dm}^{3}$ ), HPTLC RP-18W plates from Merck, polarization voltage $0.500 \mathrm{kV}$, separation time 15 min (EOF electroosmotic flow)

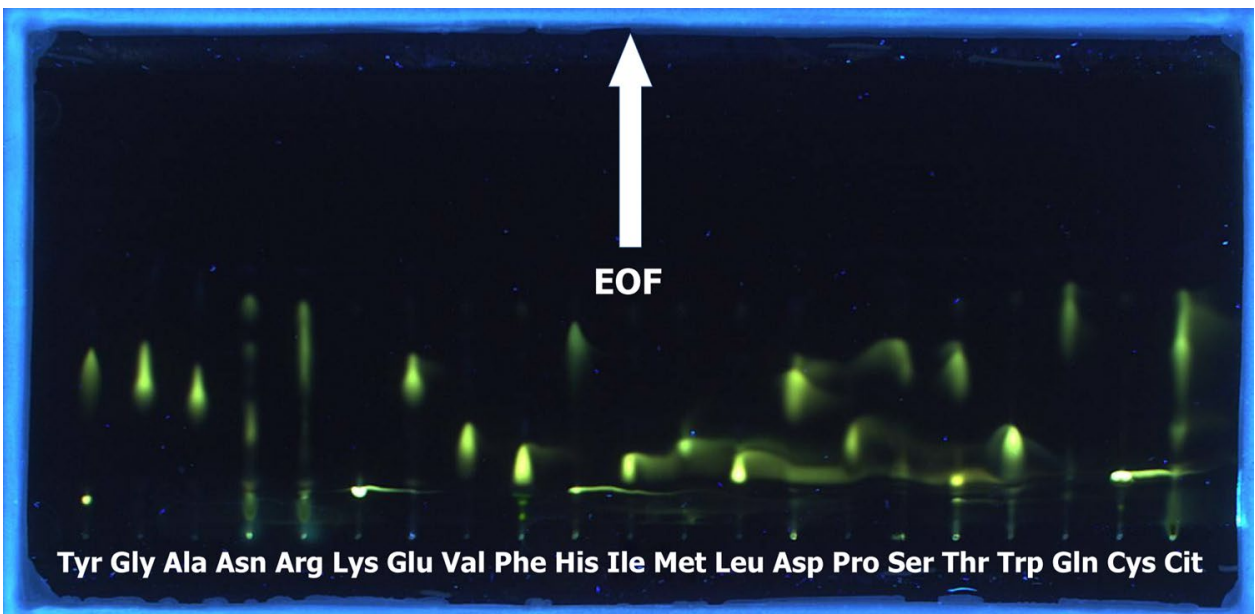

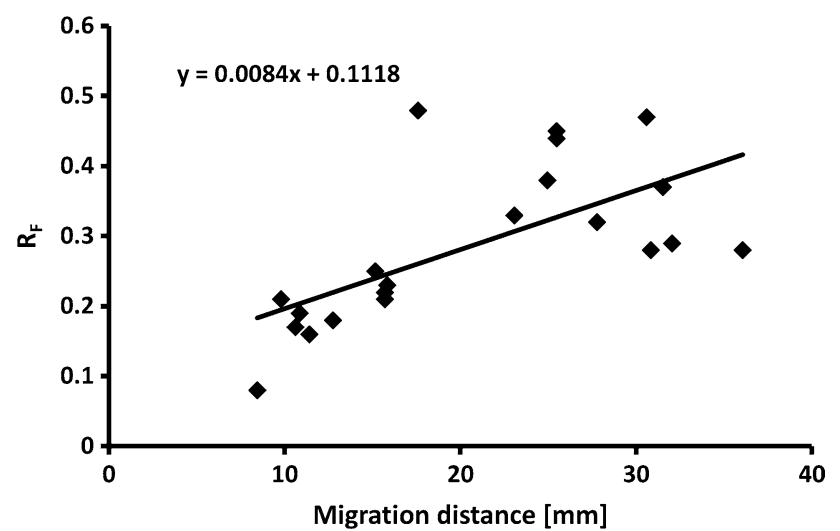

Fig. 4 Comparison of the $R_{\mathrm{F}}$ values of the DNS amino acids in HPTLC with the migration distances in PPEC. The RP-18W plates and the mobile phase comprised $40 \% \mathrm{ACN}$ in water-formic acid solution (the final formic acid concentration in the mobile phase was equal to $265 \mathrm{mmol} / \mathrm{dm}^{3}$ )

\section{Conclusion}

The data obtained show differences in the separation selectivity between HPTLC and PPEC systems with silica gel 60 $\mathrm{F}_{254 \mathrm{~s}}$ and RP-18W plates as the stationary phase. In PPEC, the electrophoretic effect is responsible for considerable separation selectivity differences relative to the HPTLC. It is an important issue because the data obtained lead to presume that the combination of HPTLC and PPEC in a two-dimensional separation process should substantially enhance DNS amino acid separation.
Acknowledgments We are grateful for the help of Ms.Sylwa Grzelak in performing of experiment part of our research.

Funding The article was developed using the equipment purchased within the agreement no. POPW.01.03.00-06-010/09-00 Operational Program Development of Eastern Poland 2007-2013, Priority Axis I, Modern Economy, Operations 1.3, Innovations Promotion.

Open Access This article is licensed under a Creative Commons Attribution 4.0 International License, which permits use, sharing, adaptation, distribution and reproduction in any medium or format, as long as you give appropriate credit to the original author(s) and the source, provide a link to the Creative Commons licence, and indicate if changes were made. The images or other third party material in this article are included in the article's Creative Commons licence, unless indicated otherwise in a credit line to the material. If material is not included in the article's Creative Commons licence and your intended use is not permitted by statutory regulation or exceeds the permitted use, you will need to obtain permission directly from the copyright holder. To view a copy of this licence, visit http://creativecommons.org/licenses/by/4.0/.

\section{References}

1. Roda JM, Pascual JM, Carceller F, González-Llanos F, PérezHigueras A, Solivera J, et al. (2000) Nonhistological diagnosis of human cerebral tumors by ${ }^{1} \mathrm{H}$ magnetic resonance spectroscopy and amino acid analysis. Clin Cancer Res 6:3983-3993

2. Pisters PWT, Pearlstone DB, Toroslan MH (1993) Protein and amino acid metabolism in cancer cachexia: investigative techniques and therapeutic interventions. Crit Rev Clin Lab Sci 30:223-272. https://doi.org/10.3109/10408369309084669

3. Herbet M, Natorska-Chomicka D, Korga A, Ostrowska M, Izdebska M, Gawrońska-Grzywacz M, et al. (2019) Altered expression of genes involved in brain energy metabolism as adaptive responses in rats exposed to chronic variable stress; changes in cortical level of glucogenic and neuroactive amino acids. Mol Med Rep 19:2386-2396. https://doi.org/10.3892/ mmr.2019.9865

4. Tajiri K, Shimizu Y (2013) Branched-chain amino acids in liver diseases. World J Gastroenterol 19:7620-7629. https://doi.org/ 10.3748/wjg.v19.i43.7620 
5. Weiss RH, Kim K (2012) Metabolomics in the study of kidney diseases. Nat Rev Nephrol 8:22-33. https://doi.org/10.1038/ nrneph.2011.152

6. Shockcor JP, Holmes E (2002) Metabonomic applications in toxicity screening and disease diagnosis. Curr Top Med Chem 2:35-51. https://doi.org/10.2174/1568026023394498

7. Huber CG, Choudhary G, Horváth C (1997) Capillary electrochromatography with gradient elution. Anal Chem 69:44294436. https://doi.org/10.1021/ac970393t

8. Huang T, Mi JQ, Zhang XX (2006) Capillary electrochromatography of amino acids with a protein-bonded porous-layer open-tubular column. J Sep Sci 29:277-281. https://doi.org/10. $1002 /$ jssc. 200500317

9. Shediac R, Ngola SM, Throckmorton DJ, Anex DS, Shepodd TJ, Singh AK (2001) Reversed-phase electrochromatography of amino acids and peptides using porous polymer monoliths. J Chromatogr A 925:251-263. https://doi.org/10.1016/S00219673(01)01036-6

10. Le A, Ng A, Kwan T, Cusmano-Ozog K, Cowan TM (2014) A rapid, sensitive method for quantitative analysis of underivatized amino acids by liquid chromatography-tandem mass spectrometry (LC-MS/MS). J Chromatogr B 944:166-174. https:// doi.org/10.1016/j.jchromb.2013.11.017

11. Harder U, Koletzko B, Peissner W (2011) Quantification of 22 plasma amino acids combining derivatization and ion-pair LC-MS/MS. J Chromatogr B 879:495-504. https://doi.org/10. 1016/j.jchromb.2011.01.010

12. Guo Y, Colón LA, Dadoo R, Zare RN (1995) Analysis of underivatized amino acids by capillary electrophoresis using constant potential amperometric detection. Electrophoresis 16:493-497. https://doi.org/10.1002/elps.1150160181

13. Kupec J, Turina S (1977) The determination of some amino acids by conventional and hot plate chromatography. Chromatographia 10:157-159. https://doi.org/10.1007/BF02297870

14. Wollenweber P (1962) Thin-layer chromatography separation of amino acids on cellulose layers. J Chromatogr 9:369-371. https:// doi.org/10.1016/s0021-9673(00)80801-8

15. Heathcote JG, Haworth C (1969) The direct determination of amino acids on thin-layer chromatograms by densitometry. Biochem J 114:667-668. https://doi.org/10.1042/bj1140667

16. Bhushan R, Ali I (1987) TLC resolution of amino acids in a new solvent and effect of alkaline earth metals. J Liq Chromatogr 10:3647-3652. https://doi.org/10.1080/01483918708077820

17. Sleckman BP, Sherma J (1982) A comparison of amino acid separations on silica gel, cellulose, and ion exchange thin layers. J Liq Chromatogr 5:1051-1068. https://doi.org/10.1080/0148391820 8067568

18. Vasta JD, Cicchi M, Sherma J, Fried B (2009) Evaluation of thin-layer chromatography systems for analysis of amino acids in complex mixtures. Acta Chromatogr 21:29-38. https://doi.org/10. 1556/achrom.21.2009.1.3

19. Baranowska I, Kozłowska M (1995) TLC separation and derivative spectrophotometry of some amino acids. Talanta 42:15531557. https://doi.org/10.1016/0039-9140(95)01569-W

20. Sherma J, Sleckman BP, Armstrong DW (1983) Chromatography of amino acids on reversed phase thin layer plates. J Liq Chromatogr 6:95-108. https://doi.org/10.1080/01483918308066873

21. Fager RS, Kutina CB (1973) Resolution of dansyl leucine and dansyl isoleucine. J Chromatogr 76:268-269. https://doi.org/10. 1016/S0021-9673(01)97808-2

22. Bhushan R, Reddy GP (1988) Some solvent systems for the resolution of dansyl amino acids by silicagel thin layer chromatography. J Liq Chromatogr 11:3163-3170. https://doi.org/10.1080/ 01483918808076786
23. Wood KR, Wang KT (1967) Separation of dansyl-amino acids by polyamide layer chromatography. Biochem Biophys Acta 133:369-370. https://doi.org/10.1016/0005-2795(67)90078-5

24. Crowshaw K, Jessup SJ, Ramwell PW (1967) Thin-layer chromatography of 1-dimethylaminonaphthalene-5-sulphonyl derivatives of amino acids present in superfusates of cat cerebral cortex. Biochem J 103:79-85. https://doi.org/10.1042/bj1030079

25. Biou D, Queyrel N, Visseaux MN, Collignon I, Pays M (1981) Separation and identification of dansylated human serum and urinary amino acids by two-dimensional thin-layer chromatography: application to aminoacidopathies. J Chromatogr 226:477-483. https://doi.org/10.1016/S0378-4347(00)86084-3

26. Wesenberg JC, Walpole JE (1980) Screening for amino acid disorders by thin-layer chromatography of the dansyl amino acids. Microchim Acta 74:1-7. https://doi.org/10.1007/BF01196480

27. Macek K, Deyl Z, Smrž M (1980) Two-dimensional thin-layer chromatography of Dns-amino acids on reversed-phase silica gel. J Chromatogr A 193:421-426. https://doi.org/10.1016/S00219673(00)87742-0

28. Nurok D, Koers JM, Novotny AL, Carmichael MA, Kosiba JJ, Santini RE, Hawkins GL, Replogle R (2004) Apparatus and initial results for pressurized planar electrochromatography. Anal Chem 76:1690-1695. https://doi.org/10.1021/ac0303362

29. Dzido TH, Mróz J, Jóźwiak GW (2004) Adaptation of a horizontal DS chamber to planar electrochromatography in a closed system. J Planar Chromatogr 17:404-410. https://doi.org/10.1556/JPC.17. 2004.6.2

30. Dzido TH, Płocharz PW, Ślązak P (2006) Apparatus for pressurized planar electrochromatography in a completely closed system. Anal Chem 78:4713-4721. https://doi.org/10.1021/ac060044b

31. Dzido TH, Płocharz PW (2007) Planar electrochromatography in a closed system under pressure-pressurized planar electrochromatography. J Liq Chromatog 30:2651-2667. https://doi.org/10. 1080/10826070701560488

32. Dzido TH, Płocharz PW, Klimek-Turek A, Torbicz A, Buszewski B (2008) Pressurized planar electrochromatography as the mode for determination of solvent composition-retention relationships in reversed-phase systems. J Planar Chromatogr 21:295-298. https:// doi.org/10.1556/jpc.21.2008.4.13

33. Dzido TH, Płocharz PW, Ślązak P, Hałka A (2008) Progress in planar electrochromatography. Anal Bioanal Chem 391:21112118. https://doi.org/10.1007/s00216-008-2009-9

34. Płocharz P, Klimek-Turek A, Dzido TH (2010) Pressurized planar electrochromatography, high-performance thin-layer chromatography and high-performance liquid chromatography: comparison of performance. J Chromatogr A 1217:4868-4872. https://doi.org/ 10.1016/j.chroma.2010.05.022

35. Chomicki A, Ślązak P, Dzido TH (2009) Preliminary results for 2-D separation with high-performance thin-layer chromatography. Electrophoresis 30:3718-3725. https://doi.org/10.1002/elps.20090 0471

36. Hałka A, Płocharz PW, Torbicz A, Dzido TH (2010) Reversedphase pressurized planar electrochromatography and planar chromatography of acetylsalicylic acid, caffeine, and acetaminophen. J Planar Chromatogr 23:420-425. https://doi.org/10.1556/jpc.23. 2010.6.7

37. Płocharz PW, Dzido TH, Ślązak P, Jóźwiak GW, Torbicz A (2007) Influence of sample application mode on performance of pressurized planar electrochromatography in completely closed system. J Chromatogr A 1170:91-100. https://doi.org/10.1016/j.chroma. 2007.08.084

38. Novotny AL, Nurok D, Replogle RW, Hawkins GL, Santini RE (2006) Results with an apparatus for pressurized planar electrochromatography. Anal Chem 78:2823-2831. https://doi.org/10. $1021 / \mathrm{ac} 052262 \mathrm{v}$ 
39. Chomicki A, Kloc K, Dzido TH (2011) Two-dimensional separation of some amino acids by HPTLC and pressurized planar electrochromatography. J Planar Chromatogr 24:6-9. https://doi. org/10.1556/jpc.24.2011.1.1

40. Chomicki A, Dzido TH, Materna-Witkowska E, Klimek-Turek A (2016) Thin-layer chromatography and pressurized planar electrochromatography of amino acids in systems with silica gel and water mobile phase. J Planar Chromatogr 29:30-37. https://doi. org/10.1556/1006.2016.29.1.4

41. Polak B, Hałka A, Dzido TH (2008) Pressurized planar electrochromatographic separation of the enantiomers of tryptophan and valine. J Planar Chromatogr 21:33-37. https://doi.org/10.1556/ jpc.21.2008.1.5

42. Polak B, Wojtanowski KK, Ślązak P, Dzido TH (2011) Separation of some aromatic amino acid enantiomers with pressurized planar electrochromatography and TLC. Chromatographia 73:339-345. https://doi.org/10.1007/s10337-010-1888-z

43. Polak B, Balasa K, Dzido TH (2013) Separation of amino acid 2,4-dinitrophenyl-5-L-valine amide diastereomeric derivatives with high-performance planar chromatography and pressurized planar electrochromatography. J Planar Chromatogr 26:180-189. https://doi.org/10.1556/jpc.26.2013.2.13

44. Polak B, Maruszak A, Płocharz PW (2016) High-performance thin-layer chromatography and pressurized planar electrochromatography of some diastereomeric amino acid derivatives in reversed-phase system with carboxylic acid mobile phase buffers. J Planar Chromatogr 29:22-29. https://doi.org/10.1556/1006. 2016.29.1.3

45. Polak B, Garbacz P (2015) $\beta$-Cyclodextrin as the mobile phase component for separation of some DNS-amino acid enantiomers with HPTLC and PPEC. Curr Anal Chem 11:68-77. https://doi. org/10.2174/1573411010666141127211110

46. Gwarda RŁ, Tomczyszyn A, Misicka A, Dzido TH (2015) Retention and separation efficiency of some synthetic oligopeptides in reversed-phase thin-layer chromatography. Acta Chromatogr 27:1-14. https://doi.org/10.1556/achrom.27.2015.1.1

47. Gwarda RŁ, Aletańska-Kozak M, Klimek-Turek A, ZiajkoJankowska A, Matosiuk D, Dzido TH (2016) Influence of carboxylic ion-pairing reagents on retention of peptides in thinlayer chromatography systems with $\mathrm{C} 18$ silica-based adsorbents. J Chromatogr A 1440:229-239. https://doi.org/10.1016/j.chroma. 2016.02.065
48. Gwarda RŁ, Dzido TH (2018) The influence of $\mathrm{pH}$ on retention and migration of peptides in systems with octadecyl silica-based adsorbent by high-performance thin-layer chromatography and pressurized planar electrochromatography techniques. J Chromatogr A 1534:179-187. https://doi.org/10.1016/j.chroma.2017.12. 063

49. Gwarda RŁ, Dzido TH (2018) The influence of addition of ionpairing acid and organic modifier of the mobile phase on retention and migration of peptides in pressurized planar electrochromatography system with octadecyl silica-based adsorbent. J Chromatogr A 1558:77-84. https://doi.org/10.1016/j.chroma.2018.05.023

50. Gwarda RŁ, Dzido TH (2018) Correlation of migration distance of peptides in high-performance thin-layer chromatography and pressurized planar electrochromatography systems. Chromatographia 81:1589-1594. https://doi.org/10.1007/s10337-018-3602-5

51. LeFevre JW, Dodsworth DW (2000) Complete analysis of a biologically active tetrapeptide: a project utilizing thin-layer chromatography and mass spectrometry. J Chem Educ 77:503-504. https://doi.org/10.1021/ed077p503

52. LeFevre JW, Gublo EJ, Botting C, Wall R, Nigro A, Pham MLT, Ganci G (2000) Qualitative reversed-phase thin-layer chromatographic analysis of the stereochemistry of D- and L-alpha-amino acids in small peptides. J Planar Chromatogr 13:160-165

53. Hałka-Grysinska A, Ślązak P, Torbicz A, Sajewicz M, Dzido TH (2013) A modified device for pressurized planar electrochromatographyand preliminary results with on-line sample application. Chromatographia 76:1271-1279. https://doi.org/10.1007/ s10337-013-2430-x

54. Chomicki A, Dzido TH (2021) Thin layer chromatography of DNS amino acids derivatives in HPTLC systems with silica gel and silanized silica gel plates: submitted to Curr. Issues Pharm Med Sci

55. Gwarda RŁ, Aletańska-Kozak M, Matosiuk D, Dzido TH (2016) Inversion of type of separation system in planar chromatography of peptides, using C18 silica-based adsorbents. J Chromatogr A 1440:240-248. https://doi.org/10.1016/j.chroma.2016.02.064

56. Gwarda RŁ, Dzido TH (2013) Two-dimensional high-performance thin-layer chromatography of tryptic bovine albumin digest using normal- and reverse-phase systems with silanized silica stationary phase. J Chromatogr A 1312:152-154. https://doi.org/10. 1016/j.chroma.2013.08.082 